\title{
Hubungan tingkat aktivitas fisik dengan tingkat depresi pada mahasiswa tahun kedua Program Studi Kedokteran Fakultas Kedokteran Universitas Tanjungpura
}

\author{
Dwi Resqy Amana ${ }^{1, *}$, Wilson², Ery Hermawati ${ }^{3}$ \\ ${ }^{1}$ Program Studi Kedokteran, Fakultas Kedokteran, Universitas Tanjungpura, Kalimantan Barat, Indonesia \\ ${ }^{2}$ Rumah Sakit Jiwa Provinsi Kalimantan Barat, Singkawang, Kalimantan Barat, Indonesia \\ ${ }^{3}$ Departemen Fisiologi, Fakultas Kedokteran, Universitas Tanjungpura, Kalimantan Barat, Indonesia \\ *Korespondensi: $\underline{\text { dwiresqyamana@student.untan.ac.id }}$
}

\begin{abstract}
Abstrak
Latar belakang: Peningkatan gejala depresi terjadi pada mahasiswa kedokteran tahun kedua disebabkan beban berat dan materi pembelajaran yang semakin sulit. Padatnya jadwal perkuliahan dan kegiatan kemahasiswaan menyebabkan kurangnya aktivitas fisik yang akan berhubungan dengan peningkatan gejala depresi. Metode: Penelitian ini merupakan penelitian analitik dengan desain potong lintang dan menggunakan teknik total sampling dengan jumlah subjek penelitian 93 mahasiswa Program Studi Kedokteran Fakultas Kedokteran Universitas Tanjungpura tahun kedua. Alat ukur penelitian menggunakan kuesioner Global Physical Activity Questionnaire (GPAQ) untuk mengukur tingkat aktivitas fisik dan Beck Depression Inventory II (BDI II) untuk mengukur tingkat depresi. Data dianalisis menggunakan uji korelasi Spearman Rank. Hasil: Berdasarkan uji statistik didapatkan nilai $p=0,707$ dengan nilai koefisien korelasi $(r)=-0,040$. Kesimpulan: Tidak terdapat hubungan antara tingkat aktivitas fisik dan tingkat depresi pada mahasiswa tahun kedua Program Studi Kedokteran Fakultas Kedokteran Universitas Tanjungpura.
\end{abstract}

Kata kunci: aktivitas fisik, depresi, mahasiswa

\section{Relationship between physical activity and depression level among second-year medical students at Faculty of Medicine Tanjungpura University}

\begin{abstract}
Background: An increase in depressive symptoms occurs among second-year medical students due to heavy burdens and increasingly difficult learning materials. Busy schedules and extracurricular activities may result in lack of physical activity which is associated with an increase in depressive symptoms. Methods: This research was a cross-sectional analytic study using total sampling technique. Ninety three second-year students at Faculty of Medicine Tanjungpura University participated in the study. Physical activity and depression level were measured using Global Physical Activity Questionnaire (GPAQ) questionnaire and Beck Depression Inventory-II (BDI II), respectively. Data was analyzed using the Spearman Rank correlation test. Results: Statistical analysis showed p-value of 0.707 with a correlation coefficient (r) of -0.040 . Conclusions: There is no relationship between level of physical activity and depression level among second-year medical students at Faculty of Medicine Tanjungpura University.
\end{abstract}

Keywords: physical activity, depression, students

\section{Pendahuluan}

Kedokteran merupakan salah satu jurusan di
Perguruan Tinggi yang dinilai penuh dengan tekanan dan diperlukan upaya serta kerja keras dalam menempuhnya. ${ }^{1}$ Fakultas kedokteran dikenal sebagai 
lingkungan dengan beban yang tinggi dan sering memberikan efek negatif pada kemampuan akademik, kesehatan psikis dan kesejahteraan psikologis mahasiswa. $^{2}$ Beratnya masa pendidikan membuat mahasiswa kedokteran lebih rentan untuk mengalami depresi. Perkembangan gejala depresi dapat dengan mudah terjadi akibat tekanan dan kehidupan yang berat selama menjalani jenjang pendidikan. ${ }^{3}$

Depresi merupakan suatu gangguan yang ditandai dengan kesedihan, kehilangan minat atau kesenangan, perasaan bersalah atau harga diri rendah, gangguan tidur atau makan, merasa kelelahan, dan buruknya konsentrasi. Berdasarkan WHO, pada tahun 2015 secara global total manusia yang mengalami depresi diperkirakan lebih dari 300 juta jiwa atau sekitar 4,4\% populasi dunia. ${ }^{4}$ Dalam skala nasional, menurut data Riskesdas tahun 2013 prevalensi orang dengan gangguan mental emosional disertai gejala depresi dan kecemasan untuk usia 15 tahun ke atas mencapai $6 \%$ dari populasi penduduk Indonesia. ${ }^{5}$ Pada tahun 2018, angka kejadian depresi di Indonesia meningkat jadi sebesar 6,1\%. ${ }^{6}$ Hasil penelitian Hadianto di Fakultas Kedokteran Universitas Tanjungpura menyatakan data prevalensi gejala depresi paling banyak pada tahun kedua (39,4\%). Gejala depresi memuncak pada tahun kedua disebabkan oleh materi pembelajaran dan keterampilan klinis yang semakin berat. $^{3}$

Salah satu pencegahan yang dapat dilakukan untuk menghindari risiko perkembangan depresi adalah dengan melakukan aktivitas fisik. ${ }^{7}$ Padatnya jadwal perkuliahan membuat mahasiswa kedokteran kurang melakukan kegiatan fisik. Penelitian Riskawati di Fakultas Kedokteran Universitas Brawijaya menyatakan mayoritas mahasiswa memiliki aktivitas fisik rendah $(60 \%) .{ }^{8}$ Penelitian lain yang dilakukan pada mahasiswa kedokteran di Universitas Sebelas Maret, didapatkan sebanyak 15,24\% mahasiswa memiliki tingkat aktivitas fisik rendah dan 50,47\% memiliki tingkat aktivitas fisik sedang. ${ }^{9}$

Sund ${ }^{10}$ menyatakan bahwa membiarkan tubuh terus menetap dengan tidak melakukan aktivitas merupakan faktor risiko pengembangan gejala depresi tingkat tinggi. Penelitian Thurai dan Westa ${ }^{11}$ menunjukkan adanya hubungan aktivitas fisik dan depresi yaitu mahasiswa yang aktif melakukan aktivitas fisik cenderung tidak mengalami depresi. Sedangkan mahasiswa dengan aktivitas fisik ringan lebih banyak memiliki depresi ringan dan sedang.

Mahasiswa kedokteran memiliki tanggung jawab dan beban berat. Semakin sulit materi pembelajaran yang harus dihadapi pada tahun kedua menjadi penyebab meningkatnya gejala depresi. Selain itu, jadwal perkuliahan yang padat dan kegiatan kemahasiswaan seperti organisasi dapat menyita waktu yang berdampak pada tingkat aktivitas fisik. ${ }^{3,8}$ Kurangnya aktivitas fisik berhubungan dengan peningkatan gejala depresi, sebagaimana penelitian di Universitas Udayana dimana mahasiswa dengan aktivitas fisik ringan didominasi memiliki gejala depresi tingkat ringan dan sedang. Penelitian ini dilakukan pada mahasiswa tingkat akhir yaitu semester tujuh. Penelitian lainnya menyatakan pada tahun kedua telah ditemukan mahasiswa dengan gejala depresi sebesar $30,99 \% .^{10-12}$ Berdasarkan hal tersebut, peneliti tertarik untuk meneliti hubungan antara tingkat aktivitas fisik dengan tingkat depresi pada mahasiswa tahun kedua Program Studi Kedokteran Fakultas Kedokteran Universitas Tanjungpura dengan harapan agar dapat sedini mungkin mencegah depresi pada mahasiswa kedokteran.

\section{Metode}

Desain penelitian ini adalah analitik dengan pendekatan potong lintang. Penelitian ini dilakukan pada tahun 2019-2020 dengan jumlah partisipan yang dilibatkan dalam penelitian adalah 93 orang dengan kriteria inklusi yaitu mahasiswa angkatan 2018 Program Studi Kedokteran Fakultas Kedokteran Universitas Tanjungpura yang sedang aktif mengikuti kegiatan perkuliahan. Teknik sampling yang digunakan pada penelitian ini adalah total sampling. Pengumpulan data dilakukan dengan menggunakan kuesioner Global Physical Activity Questionnaire (GPAQ) untuk mengukur tingkat aktivitas fisik dan Beck Depression Inventory II (BDI II) untuk mengukur tingkat depresi.

\section{Hasil}

Penelitian ini dilaksanakan pada tanggal 2 Juni 2020 melalui Google form secara daring pada mahasiswa angkatan 2018 Program Studi Kedokteran Fakultas Kedokteran Universitas Tanjungpura yang berjumlah 93 orang sesuai kriteria inklusi.

\section{Analisis univariat}

Hasil analisis menunjukkan bahwa subjek 
terbanyak pada penelitian ini adalah perempuan $(69,9 \%)$, tingkat aktivitas fisik mahasiswa dengan persentase tertinggi yaitu aktivitas fisik tingkat rendah $(61,3 \%)$, serta memiliki persentase terbesar pada tingkat depresi normal/tidak depresi $(66,7 \%)$.

Tabel 1. Distribusi subjek penelitian

\begin{tabular}{llcc}
\hline \multirow{2}{*}{ No } & \multirow{2}{*}{ Karakteristik } & \multicolumn{2}{c}{ Frekuensi } \\
\cline { 3 - 4 } & & $\mathrm{n}$ & $\%$ \\
\hline 1 & Jenis Kelamin & & \\
& Laki - laki & 28 & 30,1 \\
\multirow{2}{*}{2} & Perempuan & 65 & 69,9 \\
& Tingkat Aktivitas Fisik & & \\
& Rendah & 57 & 61,3 \\
& Sedang & 27 & 29,0 \\
& Tinggi & 9 & 9,7 \\
Tingkat Depresi & & \\
& Normal/Tidak depresi & 62 & 66,7 \\
& Depresi ringan & 16 & 17,2 \\
& Depresi sedang & 8 & 8,6 \\
Depresi berat & 7 & 7,5 \\
\hline
\end{tabular}

Sumber: Data Primer, 2020.

\section{Analisis univariat}

Analisis bivariat berfungsi untuk mencari hubungan antara tingkat aktivitas fisik dan tingkat depresi pada mahasiswa tahun kedua Program Studi Kedokteran Fakultas Kedokteran Universitas Tanjungpura. Analisis bivariat pada penelitian ini dilakukan dengan menggunakan uji korelasi Spearman Rank yang menunjukkan nilai $\mathrm{p}=0.707$. Hal ini berarti korelasi antara tingkat aktivitas fisik dan tingkat depresi tidak signifikan secara statistik. Nilai koefisien korelasi (r) adalah -0,040 yang berarti korelasi kedua variabel tidak searah.

\section{Pembahasan}

Mahasiswa tahun kedua Program Studi Kedokteran Fakultas Kedokteran Universitas Tanjungpura berdasarkan hasil analisis didominasi oleh jenis kelamin perempuan.

Mahasiswa pada penelitian ini paling banyak memiliki tingkat aktivitas fisik rendah (61,3\%). Hal ini sesuai dengan penelitian Riskawati (2018) yang menyatakan bahwa $60 \%$ mahasiswa kedokteran memiliki tingkat aktivitas fisik rendah. ${ }^{8}$ Studi yang dilakukan pada mahasiswa Fakultas Kedokteran Universitas Udayana oleh Habut et al. juga menunjukkan hasil bahwa mahasiswa paling banyak memiliki tingkat aktivitas fisik rendah (38,3\%). Hal ini dapat disebabkan karena rasa malas, kelelahan, bosan, tidak memiliki fasilitas olahraga, dan kurangnya waktu. ${ }^{13}$

Situasi pandemi COVID-19 yang terjadi bertepatan dengan pelaksanaan penelitian ini juga menjadi faktor yang mengganggu aktivitas rutin harian dikarenakan arahan pemerintah kepada masyarakat untuk tetap di rumah, melakukan isolasi diri, pembatasan kegiatan di luar ruangan termasuk aktivitas fisik rutin dan olahraga. ${ }^{14}$ Perubahan dalam rutinitas sehari-hari setiap orang di seluruh dunia sebagai akibat pandemi COVID-19 menyebabkan kurangnya aktivitas fisik dan kebiasaan sedentary yang terus berlanjut. ${ }^{15}$

Sebanyak 31 mahasiswa $(33,3 \%)$ mengalami depresi. Hasil ini menunjukkan tingginya angka kejadian depresi pada mahasiswa jika dibandingkan dengan prevalensi kejadian depresi remaja usia 15-24 tahun $(6,2 \%)$ dan masyarakat secara umum dengan prevalensi seumur hidup untuk depresi mayor yaitu 517\% sedangkan depresi minor sekitar 10\%.6.,16 Tingginya kejadian depresi pada mahasiswa kedokteran Universitas Tanjungpura dapat terkait beberapa faktor seperti jenis kelamin, jalur masuk, tempat tinggal, kondisi finansial, dan mekanisme koping. ${ }^{3}$ Selain itu, situasi pandemi COVID-19 juga telah mengakibatkan stres yang luar biasa secara global disebabkan kehilangan pekerjaan, kematian anggota keluarga, teman, atau rekan kerja, isolasi diri terutama bagi individu yang tinggal sendiri. ${ }^{17}$ Mahasiswa kedokteran juga banyak menghadapi tantangan selama pandemi ini seperti perubahan sistem perkuliahan langsung menjadi perkuliahan jarak jauh, pembatasan sosial, masalah keuangan yang berdampak pada kesehatan mental mahasiswa. ${ }^{18}$

Penelitian ini menggunakan uji korelasi Spearman Rank untuk menguji hipotesis. Hasil yang didapatkan yaitu nilai $\mathrm{p}=0,707$ dan $\mathrm{r}=-0,040$. Hasil uji menunjukkan bahwa tidak terdapat hubungan yang bermakna secara statistik antara tingkat aktivitas fisik dan tingkat depresi pada subjek penelitian $(\mathrm{p}>0,05)$. Nilai r sebesar -0,040 menunjukkan bahwa terdapat korelasi negatif antara kedua variabel. Korelasi negatif tersebut bermakna hubungan kedua variabel tidak searah yang berarti semakin tinggi tingkat aktivitas fisik maka tingkat depresi yang dialami akan menurun.

Korelasi negatif kedua variabel pada penelitian ini bertentangan dengan penelitian Hermanto (2020) yang menyatakan subjek penelitian dengan aktivitas fisik tinggi memiliki prevalensi depresi lebih 
banyak. ${ }^{19}$ Hasil ini lebih sesuai dengan penelitian Kurnia (2020) yang menyatakan semakin tinggi tingkat aktivitas fisik maka tingkat depresi akan semakin rendah..$^{20}$ Thurai (2017) menjelaskan bahwa mahasiswa yang memiliki tingkat aktivitas fisik sedang dan tinggi cenderung tidak memiliki depresi dimana aktivitas fisik tingkat sedang dikaitkan dengan penurunan risiko gejala depresi. ${ }^{11}$

Hasil penelitian ini tidak menemukan adanya hubungan yang signifikan antara tingkat aktivitas fisik dan tingkat depresi. Hal ini bertentangan dengan beberapa penelitian sebelumnya yang menunjukkan hasil signifikan pada kedua variabel dan menyatakan bahwa aktivitas fisik merupakan faktor penting dalam penurunan risiko maupun gejala depresi. ${ }^{21,22}$ Penelitian ini memiliki hasil yang serupa dengan penelitian Hermanto dimana aktivitas fisik dan kejadian depresi tidak memiliki hubungan yang signifikan secara statistik. ${ }^{19}$ Toseeb et al. juga melaporkan bahwa gejala depresi tidak signifikan diprediksi oleh aktivitas fisik. ${ }^{23}$ Hal ini dapat disebabkan oleh banyak faktor lain yang mempengaruhi tingkat depresi yang tidak dikendalikan dalam penelitian ini seperti faktor biologi, psikologi/kepribadian, mekanisme koping, dan sosial. ${ }^{24}$

Yadav et al. menyebutkan depresi pada mahasiswa kedokteran dipengaruhi oleh masalah dalam keluarga, tinggal di kos, substance abuse yaitu penyalahgunaan zat psikoaktif seperti alkohol, heroin, kokain dan obat-obatan terlarang lainnya, serta riwayat depresi dalam keluarga. ${ }^{2,25}$ Tekanan yang berat berkaitan dengan kurikulum pendidikan seperti ujian, kurangnya waktu, materi yang terlalu banyak untuk dipelajari, masalah ekonomi, pengurangan waktu tidur, serta masalah-masalah lain yang dihadapi menjadi stressor yang dapat memicu timbulnya depresi. ${ }^{26}$

Aktivitas fisik dapat mempengaruhi kesehatan mental melalui tiga mekanisme yaitu fisiologis, psikologis, dan imun. Manfaat aktivitas fisik terhadap kesehatan berdasarkan mekanisme fisiologis antara lain meningkatkan hormon endorfin yang berhubungan dengan perasaan positif sehingga dapat meningkatkan suasana hati, peningkatan suhu tubuh khususnya batang otak akan menurunkan ketegangan otot dan memberikan efek relaksasi, meningkatkan mitokondriogenesis dimana mitokondria berperan dalam neuroplastisitas yang berfungsi untuk adaptasi terhadap stres, meningkatkan mTOR yang berguna dalam mengurangi depresi, serta meningkatkan neurotransmitter seperti serotonin dan dopamin yang memiliki efek yang sama dengan selective serotonin reuptake inhibitors (SSRI) sebagai antidepresan. Mekanisme psikologis yang terjadi pada aktivitas fisik dalam meningkatkan kesehatan mental melalui pengalihan dari pikiran negatif dan timbulnya kepercayaan diri. Berdasarkan mekanisme imun, olahraga dapat mengurangi inflamasi yang diyakini sebagai salah satu patogenesis depresi. Efek antiinflamasi yang timbul dari olahraga terjadi melalui mekanisme perubahan pelepasan sitokin, pengurangan massa lemak viseral, down regulation dari toll-like receptor, dan peningkatan tonus vagal. ${ }^{27,28}$

Penelitian ini mengukur aktivitas fisik secara umum yang dihubungkan dengan tingkat depresi, sedangkan aktivitas fisik sendiri terbagi atas aktivitas fisik harian, latihan fisik, dan olahraga. ${ }^{29}$ Aktivitas fisik di waktu luang seperti latihan fisik dan olah raga lebih bermanfaat dalam kesehatan mental dibandingkan aktivitas fisik saat bekerja maupun aktivitas rumah tangga. ${ }^{30}$ Namun, penelitian Cherubal et al. di India menunjukkan hanya sedikit studi yang melaporkan hubungan antara latihan fisik dan depresi. ${ }^{31}$ Studi meta-analisis oleh White et al. menyatakan bahwa aktivitas fisik tidak secara konsisten dikaitkan dengan kesehatan mental, terdapat faktor lain seperti pengalihan terhadap stres dan motivasi. Aktivitas fisik yang dilakukan dalam lingkup sosial dapat menciptakan interaksi sehingga mengalihkan pikiran stres namun tidak pada aktivitas bekerja yang justru pekerjaan itu menjadi sumber stresnya. $^{30}$ VanKim et al. menyatakan bahwa sosialisasi menjadi media yang memberikan manfaat positif dari aktivitas fisik berat pada kesehatan mental. ${ }^{32}$ Motivasi dalam melakukan aktivitas fisik juga mendukung timbal balik yang akan terjadi, seperti latihan fisik yang dilakukan atas kemauan diri akan menghasilkan kepuasan dan manfaat bagi kesehatan mental, sedangkan aktivitas fisik atas dasar paksaan orang lain malah memberikan efek buruk. ${ }^{30}$

Rendahnya tingkat aktivitas fisik tidak bisa disebut sebagai penyebab tunggal depresi karena terdapat banyak faktor lain yang dapat mempengaruhi suasana hati seseorang yang tidak diambil datanya dalam penelitian ini. Ngasa et al. menyebutkan faktor-faktor yang berhubungan dengan depresi pada mahasiswa kedokteran antara lain mengidap penyakit 
kronis, jenis kelamin perempuan, peristiwa besar yang baru terjadi, dan mahasiswa tingkat klinis. ${ }^{33}$

Brenneisen et al. menyatakan mahasiswa dari fakultas kedokteran yang berada di Ibu Kota dilaporkan lebih rentan memiliki gejala depresi, hal ini terkait gaya hidup di Ibu Kota seperti padatnya lalu lintas dan kekerasan yang berpengaruh pada mental mahasiswa. Masalah finansial yang sering dialami mahasiswa tahun pertama dan kedua juga dapat menjadi tekanan hidup bagi mereka. ${ }^{34}$ Wege et al. melaporkan terdapat hubungan antara masalah finansial dan kesehatan mental yang buruk. ${ }^{35}$

Faktor-faktor lain dari beberapa penelitian sebelumnya yang berhubungan dengan terjadinya depresi antara lain pola hubungan, kelelahan akademik, tingkat kecemasan yang tinggi, masalah dalam belajar, lokasi kuliah, mahasiswa dengan beasiswa kuliah, religiusitas. ${ }^{34,36,37}$

\section{Kesimpulan}

Mahasiswa tahun kedua Program Studi Kedokteran Fakultas Kedokteran Universitas Tanjungpura memiliki tingkat aktivitas fisik yaitu tingkat rendah $61,3 \%$, tingkat sedang $29 \%$, tingkat tinggi $9,7 \%$ dan tingkat depresi yaitu normal / tidak depresi $66,7 \%$, depresi ringan $17,2 \%$, depresi sedang $8,6 \%$, depresi berat $7,5 \%$ serta tidak terdapat hubungan yang signifikan antara tingkat aktivitas fisik dan tingkat depresi pada mahasiswa tahun kedua Program Studi Kedokteran Fakultas Kedokteran Universitas Tanjungpura.

\section{Konflik Kepentingan}

Tidak terdapat konflik kepentingan dalam penelitian ini.

\section{Daftar Pustaka}

1. Putri IA, Soedibyo S. Tingkat depresi peserta program pendidikan dokter spesialis ilmu kesehatan anak FKUI-RSCM dan faktor-faktor yang terkait. Sari Pediatri. 2011;13(1):70.

2. Yadav R, Gupta S, Malhotra A. A cross sectional study on depression, anxiety and their associated factors among medical students in Jhansi, Uttar Pradesh, India. Int J Community Med Public Health. 2016;3(5):120914.

3. Hadianto H. Prevalensi dan faktor-faktor risiko yang berhubungan dengan tingkat gejala depresi pada mahasiswa program studi pendidikan dokter Fakultas Kedokteran Universitas Tanjungpura [skripsi]. Pontianak: Universitas Tanjungpura; 2014.

4. World Health Organization. Depression and other common mental disorders global health estimates. Geneva; 2017.

5. Kementerian Kesehatan Republik Indonesia. Laporan hasil riset kesehatan dasar (Riskesdas 2013). Balitbang Kemenkes RI. Jakarta; 2013.

6. Kementerian Kesehatan Republik Indonesia. Laporan nasional riset kesehatan dasar (Riskesdas 2018). Balitbang Kemenkes RI. Jakarta; 2018.

7. Mammen G, Faulkner G. Physical activity and the prevention of depression: a systematic review of prospective studies. Am J Prev Med. 2013;45(5):649.

8. Riskawati YK, Prabowo ED, Al Rasyid H. Tingkat aktivitas fisik mahasiswa program studi pendidikan dokter tahun kedua, ketiga, keempat. Majalah Kesehatan. 2018;5(1):27-8.

9. Utomo HS, Handayani S, Wiyono N. Hubungan aktivitas fisik dengan kapasitas memori kerja pada mahasiswa program studi kedokteran Universitas Sebelas Maret. Nexus Kedokteran Komunitas. 2016;5(2):4.

10. Sund AM, Larsson B, Wichstrøm L. Role of physical and sedentary activities in the development of depressive symptoms in early adolescence. Soc Psychiatry Psychiatr Epidemiol. 2011 May;46(5):431.

11. Thurai S, Westa W. Tingkat depresi dalam kalangan mahasiswa kedokteran semester VII Universitas Udayana dan keterlibatan mereka dalam kegiatan fisik. Intisari Sains Medis. 2017;8(2):148-9.

12. Pratiwi SE, Sukmawati F, Nisa K. Hubungan antara kepribadian dan tingkat gejala depresi pada mahasiswa tahun kedua program studi pendidikan dokter Fakultas Kedokteran Universitas Tanjungpura. J Kesehat Khatulistiwa. 2015;1(3):189.

13. Habut YM, Nurmawan SP, Wiryanthini DAI. Hubungan indeks massa tubuh dan aktivitas fisik terhadap keseimbangan dinamis pada mahasiswa Fakultas Kedokteran Universitas Udayana. Majalah Ilmiah Fisioterapi Indonesia. 2016;4(2):45-51.

14. Chen P, Mao L, Nassis GP, Harmer P, Ainsworth BE, Li F. Coronavirus disease (COVID-19): the need to maintain regular physical activity while taking precautions. J Sport Health Sci. 2020;9(2):103-104.

15. Hall G, Laddu DR, Phillips SA, Lavie CJ, Arena R. A tale of two pandemics: how will COVID-19 and global trends in physical inactivity and sedentary behavior affect one another? Prog Cardiovasc Dis. 2021;64:108-10.

16. Sadock BJ, Sadock VA, Pedro R. Kaplan and Sadock's concise textbook of clinical psychiatry. 4th ed. Philadelphia: Wolters Kluwer; 2017. 348 p.

17. Shader RI. COVID-19 and depression. Clinical Therapeutics. 2020;42(6):962-3.

18. Filho CIS, Rodrigues WC de LV, de Castro RB, Marcal AA, Pavelqueires S, Takano L, et al. Impact of COVID-19 pandemic on mental health of medical students: a cross-sectional study using GAD-7 and PHQ-9 questionnaires. Medrxiv. 2020;2.

19. Hermanto RA, Kandarina BI, Latifah L. Hubungan antara status anemia, tingkat aktivitas fisik, kebiasaan sarapan dan depresi pada remaja putri di Kota Yogyakarta. Media Gizi Mikro Indonesia. 2020;11(2):142-5.

20. Kurnia AD, Sholikhah N. Hubungan antara tingkat aktivitas fisik dengan tingkat depresi pada penderita penyakit jantung. Jurnal Kesehatan Mesencephalon. 2020;6(1):25-30.

21. Adeniyi AF, Okafor NC, Adeniyi CY. Depression and 
physical activity in a sample of nigerian adolescents: levels, relationships and predictors. Child Adolesc Psychiatry Ment Health. 2011;5:16.

22. Rebar AL, Stanton R, Geard D, Short C, Duncan MJ, Vandelanotte C. A meta-meta-analysis of the effect of physical activity on depression and anxiety in nonclinical adult populations. Health Psychol Rev. 2015;9(3):366-78.

23. Toseeb U, Brage S, Corder K, Dunn VJ, Jones PB, Owens $\mathrm{M}$, et al. Exercise and depressive symptoms in adolescents: a longitudinal cohort study. JAMA Pediatr. 2014;168(12):1093-100.

24. Dirgayunita A. Depresi: ciri, penyebab dan penangannya. Journal An-Nafs: Kajian Penelitian Psikologi. 2016;1(1):6-7.

25. McLellan AT. Substance misuse and substance use disorders: why do they matter in healthcare? Trans Am Clin Climatol Assoc. 2017;128:112-30.

26. Sari AN, Oktarlina RZ, Septa T. Masalah kesehatan jiwa pada mahasiswa kedokteran. Medula. 2017;7(4):83-5.

27. Mikkelsen K, Stojanovska L, Polenakovic M, Bosevski M, Apostolopoulos V. Exercise and mental health. Maturitas. 2017;106:48-56.

28. Wahyudi R, Bebasari E, Nazriati E. Hubungan kebiasaan berolahraga dengan tingkat stres pada mahasiswa Fakultas Kedokteran Universitas Riau tahun pertama. JOM FK. 2015;2(2):6.

29. Kementerian Kesehatan Republik Indonesia. Mengenal jenis aktivitas fisik [Internet]. Kementerian Kesehatan Republik Indonesia. 2018 [cited 2019 Aug 31]. Available from: http://promkes.kemkes.go.id/content/?p=8807

30. White RL, Babic MJ, Parker PD, Lubans DR, Astell-
Burt T, Lonsdale C. Domain-specific physical activity and mental health: a meta-analysis. Am J Prev Med. 2017;52(5):660-1.

31. Cherubal AG, Suhavana B, Padmavati R, Raghavan V. Physical activity and mental health in India: a narrative review. Int J Soc Psychiatry. 2019;65(7-8):664.

32. Vankim NA, Nelson TF. Vigorous physical activity, mental health, perceived stress, and socializing among college students. Am J Health Promot. 2013;28(1):715.

33. Ngasa SN, Sama CB, Dzekem BS, Nforchu KN, Tindong M, Aroke D, et al. Prevalence and factors associated with depression among medical students in Cameroon: a cross-sectional study. BMC Psychiatry. 2017;17(1):216.

34. Mayer FB, Santos IS, Silveira PSP, Lopes MHI, de Souza ARND, Campos EP, et al. Factors associated to depression and anxiety in medical students: a multicenter study. BMC Med Educ. 2016;16(1):282.

35. Wege N, Muth T, Li J, Angerer P. Mental health among currently enrolled medical students in Germany. Public Health. 2016;132:92-100.

36. Moutinho ILD, Maddalena NDCP, Roland RK, Lucchetti ALG, TibiriçÁ SHC, Ezequiel ODS, et al. Depression, stress and anxiety in medical students: a cross-sectional comparison between students from different semesters. Rev Assoc Med Bras. 2017;63(1):21

37. Silva V, Costa P, Pereira I, Faria R, Salgueira AP, Costa MJ, et al. Depression in medical students: insights from a longitudinal study. BMC Med Educ. 2017;17(1):184. 